\title{
Metallothionein and occupational exposure to cadmium
}

\author{
F Y FALCK JR, ${ }^{1}$ L J FINE, ${ }^{1}$ R G SMITH, ${ }^{1} \mathrm{~J}$ GARVEY,${ }^{4}$ A SCHORK, ${ }^{2}$ B ENGLAND, ${ }^{3}$ \\ K D MCCLATCHEY,${ }^{3}$ AND J LINTON ${ }^{4}$
}

From the Department of Environmental and Industrial Health, ${ }^{1}$ Department of Biostatistics, ${ }^{2}$ and Department of Pathology, ${ }^{3}$ University of Michigan, Ann Arbor, Michigan 48109, and Department of Biology, ${ }^{4}$ Syracuse University, Syracuse, New York 13210, USA

ABSTRACT The relationship between metallothionein (MT), chronic exposure to cadmium (Cd), and renal function was investigated in 53 men who were occupationally exposed to $\mathrm{Cd}$. The aim was to determine if MT is a potential biological monitor for chronic exposure to $\mathrm{Cd}$ which would be useful for preventing Cd nephropathy. In this study MT excretion, serum MT, and serum creatinine concentrations were significantly higher in subjects with abnormal renal function who had been exposed to $\mathrm{Cd}$. MT excretion was also linearly related on an individual basis to protein excretion, $\beta_{2}$-microglobulin $\left(\beta_{2}-M\right)$ excretion, and cumulative time weighted exposure (dose). MT excretion was also a better predictor of dose than either $\beta_{2}-\mathrm{M}$ excretion or $\mathrm{Cd}$ excretion. The findings suggest that MT is a potential biological monitor for chronic $\mathrm{Cd}$ exposure that would be useful for preventing $\mathrm{Cd}$-induced nephropathy. Further studies of non-specific nephropathies and MT are needed to determine if MT is a specific indicator of proximal tubule function secondary to chronic exposure to $\mathrm{Cd}$.

Metallothionein (MT) is a low molecular weight $(<10000)$ metal binding protein that was first isolated in 1957 by Margoshes and Vallee in equine kidney when they were searching for the macromolecule concerned in the accumulation of cadmium (Cd) within the renal cortex. ${ }^{1}$

MT has been identified in the cytosolic fraction of liver, kidney, and other tissues in a wide variety of animal species and man. Synthesis of MT in these tissues is inducible by cadmium, zinc, mercury, and copper. ${ }^{2}$ The exact role of MT in metal metabolism is not known, but evidence suggests that it is concerned in cellular zinc homoeostasis ${ }^{3}$ and it may be responsible for the nephrotoxicity of $\mathrm{Cd}$ observed after chronic exposure. ${ }^{4}$

Chronic industrial exposure to $\mathrm{Cd}$ can result in early renal dysfunction manifested as an increased excretion of $\boldsymbol{\beta}_{2}$-microglobulin and other low molecular weight proteins (tubular proteinuria). Increased excretion of glucose, phosphate, and amino acids has also been reported. A later effect on renal function found in Cd workers is reduced glomerular filtration and increased excretion of high molecular weight $(>60000)$ proteins. $^{s}$

Received 30 July 1982

Accepted 26 August 1982
Data from renal biopsies performed on people excessively exposed to $\mathrm{Cd}$ suggest that nephropathy develops when the concentration of $\mathrm{Cd}$ in the renal cortex exceeds $200 \mu \mathrm{g} / \mathrm{g}$ tissue. ${ }^{6}$ As indicated previously, MT is concerned in the accumulation of $\mathrm{Cd}$ in the renal cortex, but little is known about the mechanism. One current proposal supported by research on experimental animals is that MT acts as a transport molecule for $\mathrm{Cd}$ from liver to kidney. ${ }^{7} \mathrm{~A}$ low molecular weight protein such as Cd-MT would be filterable by the glomerulus and fractionally reabsorbed by the proximal tubule anatomically located in the cortex. ${ }^{8}$ If MT is concerned in the pathogenesis of renal dysfunction secondary to $\mathrm{Cd}$ exposure and is responsible for the accumulation of $\mathrm{Cd}$ in the renal cortex then it may be useful as a biological monitor for the prevention of Cd nephropathy in humans.

To examine the relationship between MT and occupational exposure to $\mathrm{Cd}$, a study of 53 men occupationally exposed to $\mathrm{Cd}$ from two separate plants (A and B) was conducted. A control group of 56 men not exposed occupationally to $\mathrm{Cd}$ was also studied. The study was designed to examine the following questions:

(1) Is there a relationship ${ }_{3}$ between cumulative time weighted exposure ( $\mu \mathrm{g} / \mathrm{m}^{3}$ years) to Cd, serum 305 
MT, or urine MT?

(2) Is there a relationship between renal function, serum MT, and urine MT?

(3) Is there a relationship between Cd in blood, $\mathrm{Cd}$ in urine, MT in serum, and MT in urine?

\section{Materials and methods}

\section{STUDY GROUPS}

\section{Plant A}

Plant A produces refrigeration compressors with copper fittings that are silver brazed. The brazing wire is $30-45 \%$ silver, $15-27 \%$ copper, $16-23 \%$ zinc, and $18-24 \%$ cadmium. A water based paste is also used with the wire that contains potassium salts of fluorine and boron. The refrigeration compressors are brazed either manually or by an automated silver brazing process. Both types of operation have local exhaust ventilation and, according to plant engineers, neither has changed since start up of the respective assembly line. The automatic line was installed in 1968, before this all silver brazing was done on the manual line.9

The air sampling data supplied by the Michigan Department of Industrial Hygiene suggest that exposures have been fairly constant over the years on both operations. Twenty breathing zone samples covering an 11 year period of operation of the automatic line were used to derive an estimated exposure of $39 \pm 7.8(\mathrm{SE}) \mu \mathrm{g} / \mathrm{m}^{3}$. Exposure on the manual line was found to be significantly higher, $110 \pm 25 \cdot 5(\mathrm{SE}) \mu \mathrm{g} / \mathrm{m}^{3} ; 61$ breathing zone samples over a 21 year period were used for the calculation of this estimate. There was no statistically significant change in exposure over the 21 year period on the manual line or the 11 year period on the automatic line; there was also no significant change of exposure with seasons $(p>0 \cdot 10){ }^{9}$

Employee work histories were obtained from the personnel department from which a summary of the time spent on the automatic versus the manual line was calculated. The following formula was then used to calculate cumulative time weighted exposure:

Time weighted exposure $=\sum_{i=1}^{n} E_{i} \cdot T_{i}$
where

$E_{i}=$ estimated inhalation exposure for a work area $i$ $T_{i}=$ time worked in area $i$

Respiratory protection has never been required or used at this plant, so the previous estimates of exposure were used without adjustment.

Thirty three male employees (group A) voluntarily agreed to participate in the study. This group consisted of 25 of 27 currently exposed workers and eight of 13 previously exposed workers. Each participant was interviewed and administered a short questionnaire to obtain histories of hypertension, Fanconi syndrome, Goodpasture's syndrome, kidney infection, nephrolithiasis, analgesic and drug use, diabetes mellitus, diabetes insipidus, and smoking habits. From each participant a spot urine sample was collected in a $125 \mathrm{ml}$ metal free polyethylene container. Each participant also donated $40 \mathrm{ml}$ of blood by venepuncture in four trace element (certified $\mathrm{Cd}$ free) vacutainers with suitable collection reagents for the specific analysis. ${ }^{9}$

\section{Plant $B$}

Plant B produces $\mathrm{Cd}$ oxide and $\mathrm{Cd}$ sulphide from flue dust collected by air pollution control equipment at non-ferrous smelters. The flue dust is shipped in bags by rail and each shipment is assayed for $\mathrm{Cd}$ when received. The $\mathrm{Cd}$ containing material is roasted, dissolved in sulphuric acid, calcined, and purified by precipitation and filtration. The solution containing $\mathrm{Cd}$ is then pumped to the electrolytic tank house where high purity $\mathrm{Cd}(95 \%)$ is produced. From here the $\mathrm{Cd}$ is transferred to the foundry where it is melted and cast into bricks. Some of the bricks are reoxidised in gas heated retorts to make Cd oxide powder. Cd containing waste and residue from the retorts are used to produce yellow $\mathrm{Cd}$ sulfide pigment. ${ }^{10}$

Exposure to $\mathrm{Cd}$ oxide dust occurs during the handling of the $\mathrm{Cd}$ oxide powder and transport of flue dust between roasting, mixing, and calcining. $\mathrm{Cd}$ fume exposure occurs during the roasting, calcining, retort, and foundry operations. Exposure to Cd sulphate mist occurs during the solution and electrolytic tankhouse operations. Exposures to lead, arsenic, thallium, and indium also occur infrequently to a few individuals in isolated locations. ${ }^{10}$

Smith et $\mathbf{l}^{10}$ have studied this population extensively. Inhalation exposures have been estimated using area sampling data adjusted by a two step process that accounts for respirator use and the relationship between area and breathing zone samples. The inhalation exposures reported by Smith et al ${ }^{10}$ were used to estimate cumulative time weighted exposure.

Work histories of each participant were estimated using records of biological monitoring data that listed the department and job title at the time the sample was taken. Biological monitoring has been carried out at the plant since about 1948. The inhalation exposures and the work history were used to calculate the cumulative time weighted exposure for each participant.

At the time the present study was conducted there were 50 employees at the plant, and 20 men (group 
B) voluntarily agreed to participate. A spot urine sample $(40 \mathrm{ml})$ was collected from each participant.

\section{Control group}

Forty one male controls not known to be occupationally exposed to cadmium were arbitrarily selected from the University of Michigan for semiquantitative and quantitative urine analysis. A $40 \mathrm{ml}$ spot urine sample was collected from each. Fifteen additional male controls were selected for measurement of serum $\beta_{2}$-microglobulin $\left(\beta_{2}-\mathrm{M}\right)$. $^{9}$

\section{SAMPLE PREPARATION AND ANALYSIS}

The $\mathrm{pH}$ of each urine sample was checked after collection and adjusted above 5.5 where necessary in those aliquots used for $\beta_{2}$-microglobulin analysis. Blood, serum, and urine samples used for semiquantitative and quantitative analysis were stored at $-70^{\circ} \mathrm{C}$. Serum and urine samples used for $\mathrm{MT}$ analysis were stored at $-20^{\circ} \mathrm{C}$. All samples were thawed at room temperature for subsequent analysis.

Semiquantitative urine analysis for $\mathrm{pH}$, protein, glucose, ketones, urobilinogen, bilirubin, and blood in urine was done using Chemstrip 7 (Biodynamics, Indianapolis, USA). Quantitative urine analysis was done for the following: $\mathrm{Cd}$, total protein, albumin, $\beta_{2}-\mathrm{M}$, glucose, creatinine, MT, specific gravity, and osmolality. Cd was analysed on a Varian 475 (Palo Alto, CA) atomic absorption spectrophotometer using NIOSH method physical and chemical analytical method 173. ${ }^{11}$ Total protein was analysed using the Quant test (Quantimetrix, Hawthorne, CA) based on the method of Bradford..$^{12}$ Albumin was measured using the Gelman (Laboratory Products Division, Ann Arbor, MI) protein electrophoresis system. $\beta_{2}-\mathbf{M}$ was determined by radioimmunoassay using the Phadebas $\boldsymbol{\beta}_{2}$-micro test (Pharmacia Diagnostics, Uppsala, Sweden). Glucose and creatinine measurements were performed on a Beckman Astra 8 (Beckman Instruments, Brea, CA). Osmolality was done using a Wescor 5100 B vapour pressure osmometer (Wescor, Inc, Logan, UT), and specific gravity was measured using a TS meter (catalogue No 10400, American Optical, Keene, NH). MT was measured by a radioimmunoassay method developed by Vander Mallie and Garvey. ${ }^{13} 14$

Serum samples were analysed for creatinine, $\beta_{2}-M$, and MT by the respective instruments and methods outlined above. Blood $\mathrm{Cd}$ was measured using a Varian 475 atomic absorption spectrophotometer equipped with a graphite furnace.

\section{DATA ANALYSIS}

The results of the quantitative urine analysis, including glucose, total protein, $\beta_{2}-\mathrm{M}, \mathrm{MT}$, and Cd were transformed for comparative purposes by being expressed per gram of creatinine. This transformation did not alter any of the statistical distributions or any of the statistical conclusions for the hypotheses investigated. A logarithmic transformation was then performed on the creatinine adjusted variables since they approximated a log-normal distribution. Linear regression analysis was used to determine the statistical relationship between MT (the dependent variable), cumulative time weighted exposure $\left(\mu \mathrm{g} / \mathrm{m}^{3}\right.$ years $)$, total protein, $\beta_{2}-\mathrm{M}$, glucose, creatinine, and Cd in groups $A$ and $B$ separately, since these groups differed ${ }_{3}$ significantly $(\mathrm{p}<0.001)$ in Cd excretion and $\mu \mathrm{g} / \mathrm{m}^{3}$ years (table 1). This was predictable since group $B$ had higher cumulative time weighted exposures than group $\mathbf{A}$ (table 2), and different methods for estimating exposure years were used for each group. The two

Table 1 Characteristics of control group and groups $A$ and $B$

\begin{tabular}{|c|c|c|c|c|c|c|c|c|}
\hline Variable & $\begin{array}{l}\text { Controls } \\
(\mathrm{n}=41\end{array}$ & & $\begin{array}{l}\text { Group } A \\
(\mathrm{n}=33)\end{array}$ & & $p$ value & $\begin{array}{l}\text { Group } B \\
(\mathrm{n}=20)\end{array}$ & & $p$ value ${ }^{*}$ \\
\hline $\begin{array}{l}\text { Age } \dagger \\
\text { Height, cm } \dagger \\
\text { Weight, } \mathbf{k g}^{\dagger}\end{array}$ & $\begin{array}{r}40 \\
178 \\
75\end{array}$ & $\begin{array}{lr} \pm & 13 \\
\pm & 7 \\
\pm & 10\end{array}$ & $\begin{array}{r}50 \\
175 \\
87\end{array}$ & $\begin{array}{lr} \pm & 6 \\
\pm & 8 \\
\pm & 13\end{array}$ & $\begin{array}{c}<0.001 \\
0.26 \\
<0.001\end{array}$ & $\begin{array}{r}50 \\
175 \\
87\end{array}$ & $\begin{array}{lr} \pm & 12 \\
\pm & 9 \\
\pm & 20\end{array}$ & $\begin{array}{l}0.001 \\
0.12 \\
0.004\end{array}$ \\
\hline $\begin{array}{l}\text { Urine } \\
\text { pH } \dagger \\
\text { Specific gravity } \dagger \\
\text { Osmolality } \dagger \\
\text { Creatinine }{ }^{\dagger} / 100 \mathrm{ml} \\
\text { Cadmium } \neq \mu g / g \text { creatinine }\end{array}$ & $\begin{array}{c}5 \cdot 8 \\
1.021 \\
843 \\
0.17\end{array}$ & $\begin{array}{lc} \pm & 0.9 \\
\pm & 0.01 \\
\pm & 292 \\
\pm & 0.08\end{array}$ & $\begin{array}{c}5 \cdot 0 \\
1.020 \\
724 \\
0 \cdot 14 \\
12 \cdot 4\end{array}$ & $\begin{array}{ll} \pm & 0.9 \\
\pm & 0.004 \\
\pm & 163 \\
\pm & 0.05 \\
\pm & 1.6\end{array}$ & $\begin{array}{c}<0.001 \\
0.37 \\
0.04 \\
0.06\end{array}$ & $\begin{array}{c}6.4 \\
1.014 \\
599 \\
0 \cdot 11 \\
23.7\end{array}$ & $\begin{array}{lc} \pm & 0.9 \\
\pm & 0.01 \\
\pm & 225 \\
\pm & 0.05 \\
\pm & 1.8\end{array}$ & $\begin{array}{c}0.03 \\
0.01 \\
0.002 \\
0.004 \\
<0.001 \S\end{array}$ \\
\hline $\begin{array}{c}\mu \mathrm{g} / \text { creatinine } \\
\mu \mathrm{g} / \mathrm{m}^{3} \text { years } \ddagger\end{array}$ & 2.4 & $2 \cdot 2$ & $\begin{array}{c}40 \cdot 8 \\
593\end{array}$ & $\begin{array}{l}3 \\
2 \cdot 5\end{array}$ & & $\begin{array}{r}33 \\
1994\end{array}$ & $\begin{array}{l}3 \\
2 \cdot 6\end{array}$ & $\begin{array}{c}0.44 \S \\
<0.001 \S\end{array}$ \\
\hline
\end{tabular}

*Student $\mathbf{t}$ test (groups $\mathbf{A}$ and $\mathbf{B}$ versus control group).

† Mean \pm SD.

$\ddagger$ Geometric mean $\pm \mathrm{SD}^{\mathrm{a}}\left(\mathrm{SD}^{\mathrm{a}}\right.$ is antilog of $\mathrm{SD}$ in log scale).

$\S$ Group A versus group B. 
Table 2 Quantitative urine analysis results expressed per gram creatinine and cumulative time weighted exposure data; cadmium exposed groups $A$ and $B^{*}$

\begin{tabular}{|c|c|c|c|c|c|c|c|}
\hline Subjects $\dagger$ & $\begin{array}{l}\text { mg Glucose/g } \\
\text { creatinine }\end{array}$ & $\begin{array}{l}\text { mg Protein/g } \\
\text { creatinine }\end{array}$ & $\begin{array}{l}\text { mg Albumin/g } \\
\text { creatinine }\end{array}$ & $\begin{array}{l}\mu_{g} \beta_{2}-M / g \\
\text { creatinine }\end{array}$ & $\begin{array}{l}\mu g M T / g \\
\text { creatinine }\end{array}$ & $\underset{\text { creatinine }}{\mu \mathrm{g} C d / \mathrm{g}}$ & $\mu g / m^{3}$ years \\
\hline $\begin{array}{l}1 \\
2 \ddagger \\
3 \\
4 \ddagger \\
5 \\
6 \\
7 \\
8 \\
9 \\
10 \\
11 \\
12 \ddagger \\
13 \\
14 \\
15 \ddagger \\
16 \\
17 \\
18 \\
19 \\
20 \ddagger \\
21 \\
22 \\
23 \\
24 \\
25 \ddagger \\
26 \\
27 \\
28 \\
29 \\
30 \\
31 \\
32 \\
33 \\
34 \ddagger \\
35 \\
36 \ddagger \\
37 \\
38 \\
39 \\
40 \\
41 \\
42 \\
43 \\
44 \\
45 \\
46 \\
51 \\
53 \\
59\end{array}$ & 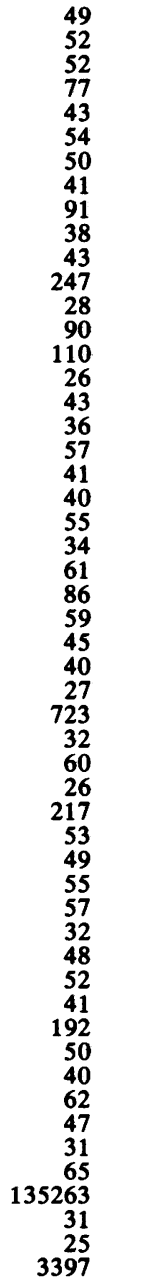 & $\begin{array}{r}33 \\
478 \\
111 \\
148 \\
43 \\
32 \\
41 \\
21 \\
103 \\
27 \\
43 \\
517 \\
28 \\
170 \\
110 \\
26 \\
57 \\
36 \\
28 \\
355 \\
20 \\
156 \\
85 \\
34 \\
321 \\
30 \\
13 \\
15 \\
21 \\
660 \\
16 \\
33 \\
104 \\
317 \\
114 \\
213 \\
69 \\
146 \\
38 \\
63 \\
36 \\
21 \\
21 \\
24 \\
73 \\
53 \\
230 \\
41 \\
37 \\
21 \\
35 \\
\end{array}$ & $\begin{array}{r}261 \\
114 \\
\\
266 \\
91 \\
197\end{array}$ & $\begin{array}{r}74 \\
644 \\
3496 \\
2278 \\
79 \\
32 \\
25 \\
21 \\
63 \\
16 \\
57 \\
61034 \\
56 \\
8920 \\
713 \\
40 \\
179 \\
86 \\
28 \\
18497 \\
79 \\
4404 \\
28 \\
109 \\
53667 \\
30 \\
13 \\
11 \\
142000 \\
633 \\
25 \\
287 \\
28241 \\
16 \\
653 \\
117 \\
19585 \\
120 \\
771 \\
301 \\
811 \\
126 \\
36 \\
72 \\
397 \\
507 \\
150 \\
86 \\
144 \\
70\end{array}$ & 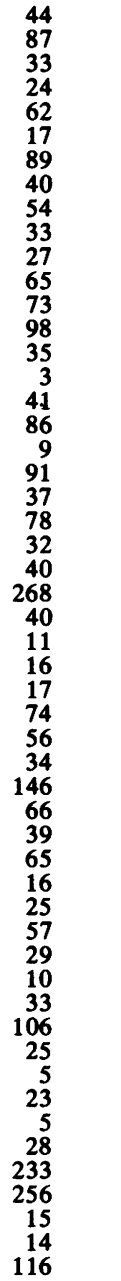 & $\begin{array}{r}12 \\
9 \\
5 \\
8 \\
10 \\
13 \\
11 \\
10 \\
10 \\
5 \\
17 \\
18 \\
13 \\
12 \\
12 \\
13 \\
11 \\
17 \\
10 \\
24 \\
10 \\
21 \\
17 \\
10 \\
61 \\
20 \\
7 \\
9 \\
14 \\
18 \\
9 \\
11 \\
21 \\
26 \\
19 \\
41 \\
41 \\
17 \\
24 \\
16 \\
15 \\
27 \\
27 \\
75 \\
12 \\
21 \\
23 \\
12 \\
24 \\
10 \\
13 \\
48\end{array}$ & $\begin{array}{r}1164 \\
904 \\
955 \\
201 \\
1020 \\
1086 \\
1079 \\
428 \\
351 \\
217 \\
486 \\
1901 \\
468 \\
1125 \\
1591 \\
18 \\
773 \\
708 \\
162 \\
1320 \\
447 \\
356 \\
1065 \\
700 \\
1996 \\
230 \\
478 \\
722 \\
725 \\
1629 \\
422 \\
574 \\
444 \\
1896 \\
2738 \\
2771 \\
430 \\
3334 \\
2263 \\
4640 \\
2747\end{array}$ \\
\hline
\end{tabular}

* Reference tolerance limits: $130 \mathrm{mg}$ glucose/g creatinine, $172 \mathrm{mg}$ protein $/ \mathrm{g}$ creatinine, $629 \mu \mathrm{g} \boldsymbol{\beta}_{\mathbf{2}}-\mathrm{M} / \mathrm{g}$ creatinine.

Note: Control geometric mean $\pm \mathrm{SE}^{\mathrm{a}}$ ( $\left(\mathrm{SE}^{\mathrm{a}}\right.$ is antilog of $\mathrm{SE}$ in $\log$ scale): $47 \mathrm{mg}$ glucose/g creatinine $\pm 1 \cdot 1,39 \mathrm{mg}$ protein/g creatinine $\pm 1 \cdot 0$, $83 \mu \mathrm{g} \beta, \mathbf{M} / \mathrm{g}$ creatinine $\pm 1 \cdot 2,2 \cdot 4 \mu \mathrm{g}$ MT/g creatinine $\pm 1 \cdot 2$.

†Subjects 1-33 group $A$, subjects 34-53 group B.

¥Subjects classified as having abnormal renal function-that is, exceeded reference tolerance limits for two of three urine variables or were albuminuric and exceeded one upper reference tolerance limit.

groups did not differ in MT excretion $(p=0.44)$. For each regression equation the T-statistic was calculated and the level of significance determined.

To examine the relationship between MT and renal status in the study group, tolerance limits (0.95) were calculated from the control group data for each variable. If a subject exceeded the upper limit on two or more of the following urine variables-glucose, total protein, and $\beta_{2}-\mathrm{M}-$ or had albuminuria and exceeded the upper limit on one of the urine variables his renal function was classified as abnormal. This decision rule is supported by evidence that $\mathrm{Cd}$ can effect both proximal tubule and glomerular function. ${ }^{5}$ The Student $t$ test was used to 
Table 3 Renal function and significance of biological variables, cadmium exposed groups $A$ and $B$

\begin{tabular}{|c|c|c|c|c|c|c|c|c|c|c|c|}
\hline \multirow[b]{3}{*}{$\begin{array}{l}\text { Age* } \\
\text { Urine metallothionein } \dagger \\
(\mu g / g \text { creatinine })\end{array}$} & \multicolumn{5}{|c|}{ Group A } & \multicolumn{3}{|l|}{ Group B } & \multicolumn{3}{|c|}{ Groups $A$ and $B$} \\
\hline & \multicolumn{2}{|c|}{$\begin{array}{l}\text { Abnormal } \\
(n=6)\end{array}$} & \multicolumn{2}{|c|}{$\begin{array}{l}\text { Normal } \\
(n=26)\end{array}$} & \multirow{2}{*}{$\begin{array}{c}p \text {-value } \\
0.08 \\
0.09\end{array}$} & \multirow{2}{*}{$\begin{array}{c}\begin{array}{c}\text { Abnormal } \\
(n=3)\end{array} \\
57 \pm 2 \\
79 \pm 1 \cdot 2\end{array}$} & \multirow{2}{*}{$\begin{array}{c}\begin{array}{l}\text { Normal } \\
(n=16)\end{array} \\
48 \pm 3 \\
25 \pm 1 \cdot 3\end{array}$} & \multirow{2}{*}{$\begin{array}{l}p \text {-value } \\
0.22 \\
0.07\end{array}$} & \multirow{2}{*}{$\begin{array}{l}\begin{array}{c}\text { Abnormal } \\
(n=9)\end{array} \\
72 \pm 1.3\end{array}$} & \multirow{2}{*}{$\begin{array}{l}\begin{array}{l}\text { Normal } \\
(n=42)\end{array} \\
31 \pm 1 \cdot 2\end{array}$} & \multirow{2}{*}{$\begin{array}{c}p \text {-value } \\
0.01\end{array}$} \\
\hline & $\begin{array}{l}54 \\
69\end{array}$ & $\begin{array}{l} \pm 1 \\
\pm 0.4\end{array}$ & $\begin{array}{l}49 \\
36\end{array}$ & $\begin{array}{l} \pm 1 \\
\pm 1 \cdot 2\end{array}$ & & & & & & & \\
\hline Urine cadmiumt & 17 & \pm 1.4 & 11 & \pm 1 & 0.09 & $37 \pm 1 \cdot 2$ & $20 \pm 1 \cdot 1$ & 0.07 & - & - & - \\
\hline $\begin{array}{l}\text { Urine proteint } \\
\text { (mg/g creatinine) }\end{array}$ & 275 & $\pm 1 \cdot 3$ & 39 & $\pm 1 \cdot 2$ & $<0.001$ & $186 \pm 1.4$ & $49 \pm 1 \cdot 2$ & 0.007 & & & \\
\hline $\begin{array}{l}\text { Urine } \beta_{2}-M \dagger \\
(\mu g / g \\
\text { creatinine })\end{array}$ & 6310 & $\pm 2 \cdot 4$ & 79 & \pm 1.4 & $<0.001$ & $3236 \pm 2.6$ & $162 \pm 1.4$ & 0.005 & & & \\
\hline $\begin{array}{l}\text { Serum metallothionein } \\
(\mathrm{ng} / \mathrm{ml})\end{array}$ & 3 & \pm 0.62 & 2 & \pm 0.16 & 0.02 & - & - & - & 一 & - & - \\
\hline $\begin{array}{l}\text { Serum creatinine* } \\
(\mathrm{mg} / 100 \mathrm{ml})\end{array}$ & 1.4 & \pm 0.11 & 1.06 & $6 \pm 0.04$ & 0.001 & - & - & - & - & - & - \\
\hline $\begin{array}{l}\text { Serum B -microglobulin * } \\
(\mu \mathrm{g} / \mathrm{m})\end{array}$ & & \pm 0.26 & $2 \cdot 1$ & $0 \cdot 17$ & 0.58 & - & - & - & - & - & - \\
\hline
\end{tabular}

†Geometric mean $\pm \mathrm{SE}^{\mathrm{a}}$ (SEa antilog of $\mathrm{SE}$ in the log scale).

*Arithmetic mean $\pm \mathrm{SE}$.

test the significance of the difference in MT excretion in subjects with abnormal versus normal renal function.

Linear regression analysis and analysis of variance procedures were used to examine the effect, if any, that smoking habits had on $\mathrm{Cd}$ excretion, and that age had on protein, MT, and $\beta_{2}-\mathrm{M}$ excretion.

\section{Results}

Table 1 presents the general characteristics of the control group and groups A and B. There is a significant difference in the average age and weight of groups A and B versus controls. A significant difference also exists between group $B$ and the control group in average specific gravity, osmolality, and urinary creatinine concentration. Group $A$ and the control group differ significantly in mean osmolality. No significant difference $(p>0.40)$ was found when the mean excretion of glucose, protein, and $\beta_{2}-M$ in the control group (bottom table 2) was compared with the mean excretion in subjects with normal renal function in groups A and B (table 3 ).

The quantitative urine analysis results for glucose, total protein, $\beta_{2}-\mathbf{M}, \mathbf{M T}$, and Cd expressed per gram of creatinine are listed by subject in table 2 . The reference tolerance limits calculated from the control group data are located at the bottom of table 2 . The reported reference tolerance limits agree with what would be expected for unexposed normal subjects, assuming 1-2 $\mathrm{g}$ of creatinine is excreted each day. ${ }^{\text {is }}$ Blood samples collected from group $\mathbf{A}$ were analysed for creatinine, $\boldsymbol{\beta}_{\mathbf{2}}-\mathrm{M}, \mathrm{MT}$, and Cd; results by subject are reported in table 4 . Reference tolerance limits determined from control serum samples are located at the bottom of table 3 .

Cd excretion (log $\mu \mathrm{g} / \mathrm{g}$ creatinine) differed $(p=0.06)$ between smokers, non-smokers, and ex-smokers. Smoking habits, however, did not have any significant effect on the relationship between $\mathrm{Cd}$ excretion and the other variables under study when

Table 4 Quantitative analysis of serum, cadmium exposed group $A^{* \dagger}$

\begin{tabular}{|c|c|c|c|}
\hline Subject & $\begin{array}{l}\text { Serum creatinine } \\
(\mathrm{mg} / 100 \mathrm{ml})\end{array}$ & $\begin{array}{l}\text { Serum } \beta_{3}^{-} \\
\text {microglobulin } \\
(\mu g / m l)\end{array}$ & $\begin{array}{l}\text { Serum } \\
\text { metallothionein } \\
(\mathrm{ng} / \mathrm{ml})\end{array}$ \\
\hline 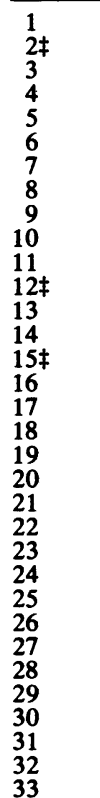 & $\begin{array}{l}1.0 \\
1.6 \\
1.3 \\
1.1 \\
1.0 \\
0.9 \\
1.1 \\
1.2 \\
1.1 \\
0.9 \\
1.0 \\
1.8 \\
0.9 \\
1.0 \\
1.5 \\
1.3 \\
1.1 \\
1.6 \\
1.1 \\
1.3 \\
0.8 \\
1.0 \\
1.1 \\
1.0 \\
1.2 \\
1.1 \\
1.1 \\
0.9 \\
1.1 \\
1.3 \\
0.5 \\
1.5 \\
0.9\end{array}$ & $\begin{array}{l}1.3 \\
1.7 \\
2.2 \\
1.9 \\
1.1 \\
2.0 \\
3.3 \\
2.8 \\
1.5 \\
2.0 \\
1.9 \\
2.4 \\
1.2 \\
3.4 \\
3.0 \\
2.2 \\
2.6 \\
1.6 \\
1.5 \\
1.8 \\
3.0 \\
2.2 \\
3.0 \\
0.2 \\
3.2 \\
1.6 \\
2.0 \\
1.3 \\
1.6 \\
3.4 \\
1.9 \\
4.1 \\
3.0\end{array}$ & $\begin{array}{r}1.4 \\
4.9 \\
1.6 \\
1.6 \\
<1.0 \\
2.4 \\
1.8 \\
1.5 \\
1.6 \\
1.6 \\
1.0 \\
1.6 \\
1.7 \\
1.6 \\
1.7 \\
1.2 \\
1.8 \\
2.8 \\
2.3 \\
3.7 \\
1.3 \\
1.3 \\
2.4 \\
1.8 \\
4.3 \\
2.1 \\
1.6 \\
1.6 \\
4.2 \\
1.8 \\
3.5 \\
3.5 \\
1.7\end{array}$ \\
\hline
\end{tabular}

*Reference tolerance limits: creatinine $1.3 \mathrm{mg} / 100 \mathrm{ml}, \beta_{2}-\mathrm{M} 3.9$ $\mu \mathrm{g} / \mathrm{ml}$.

$\dagger$ All subjects blood $\mathrm{Cd}<5 \mathrm{ng} / \mathrm{ml}$.

\#Subjects with mildly raised serum creatinine concentrations who are also classified as having abnormal renal function according to decision rule at bottom of table 2 . 
it was included as an independent factor in multifactor regression analysis. Age had no significant effect on any of the statistical relationships when included as an independent factor.

After comparing the values in table 2 with the respective reference tolerance values, it becomes apparent that subjects $2,4,12,15,20,25,34,36$, and 53 have undergone a change in renal function consistent with $\mathrm{Cd}$ exposure. Abnormal results are also reported for subjects 30 and 50 . Subject 30 , however, has a history of kidney infection and subject 50 has diabetes mellitus. These pre-existing medical conditions can lead to renal dysfunction, so these two subjects were not used in the statistical analysis of the study data. Subjects $2,4,12,15,20$, and 34 are albuminuric, and in subjects 2,12 , and 15 the serum creatinine concentration is raised (table 4). Subject 15 also has a history of nephrolithiasis. Several investigators have reported an association between nephrolithiasis and exposure to Cd. ${ }^{5}$ There is no significant difference in the average age of subjects with abnormal versus normal renal function within groups A or B (table 4).

The relationship between MT excretion and renal status was examined by comparing subjects with abnormal versus normal renal function and MT excretion within each group and after pooling both groups. Pooling of groups A and B was done with some caution since the groups differed with respect to $\mathrm{Cd}$ excretion and cumulative time weighted exposure; they did not, however, differ significantly in MT excretion. MT excretion in groups A and B combined is on the average significantly higher $(p=0.01)$ in subjects with abnormal versus normal renal function (see table 3 ). MT excretion is also higher within each group for subjects with abnormal versus normal renal function. The level of significance (group $\mathrm{A}, \mathrm{p}=0.09 ;$ group $\mathrm{B}$, $p=0.07$ ), however, is much less, and this is possibly due to the smaller sample size within each group. Serum creatinine $(p=0.001)$ and serum MT $(p=0.02)$ are, on the average, significantly higher in the subjects with abnormal versus normal renal function within group A (table 4). MT excretion is linearly related to protein and $\beta_{2}-\mathrm{M}$ excretion in groups $A(p=0.001, p=0.004$; figs 1,2 respectively) and $B(p=0.008, p<0.001$; figs 1,2 respectively). These relationships suggest that MT concentrations in urine or serum are related to renal function.

Excretion of MT is also linearly related to cumulative time weighted exposure in group $A(p<0.001$, fig 3 ) and group $B(p=0.09$, fig 3$)$. Cd excretion is not significantly linearly related to cumulative time weighted exposure in group $\mathrm{A}\left(\mathrm{r}^{2}=0.06, \mathrm{p}=0.20\right)$ or group $B\left(r^{2}=0.04, p=0.44\right)$. Excretion of MT and $\mathrm{Cd}$ are linearly related both in group $\mathrm{A}$ $(p=0.009$, fig 4$)$ and group B ( $=0.07$, fig 4$)$. It should be indicated that in fig 4 the lowest point for group A shifts the line somewhat. If this point is removed the correlation improves $\left(r^{2}=0.32\right)$; there

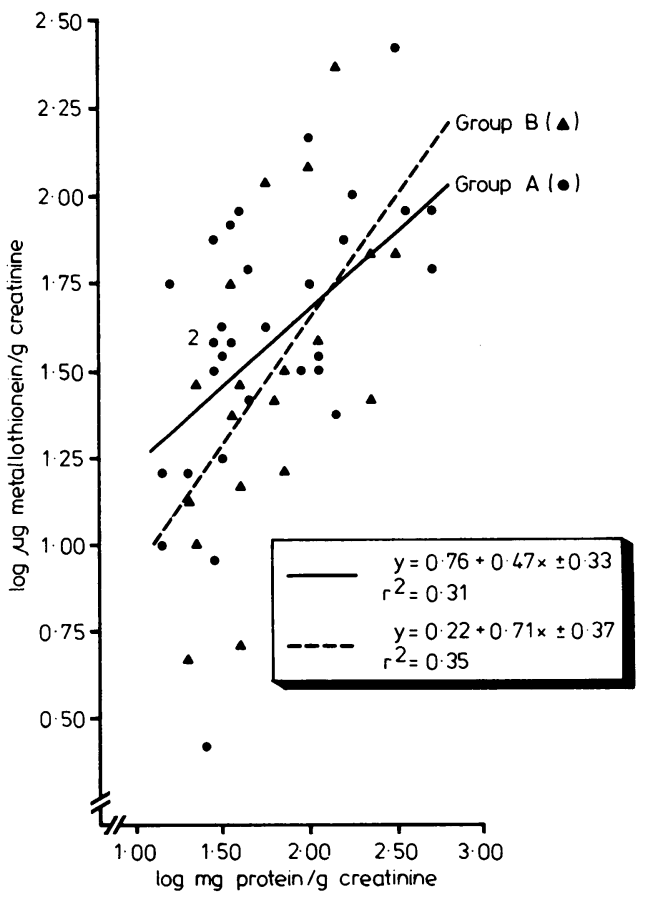

Fig 1 Urinary excretion of metallothionein and protein, cadmium exposed group $A$ and group $B$.

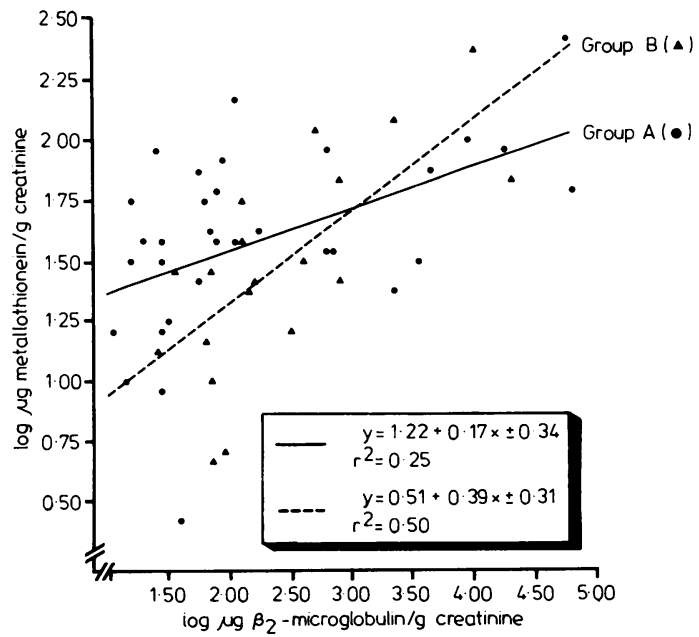

Fig 2 Urinary excretion of metallothionein and $\beta_{2}$-microglobulin, cadmium exposed group $A$ and group $B$. 


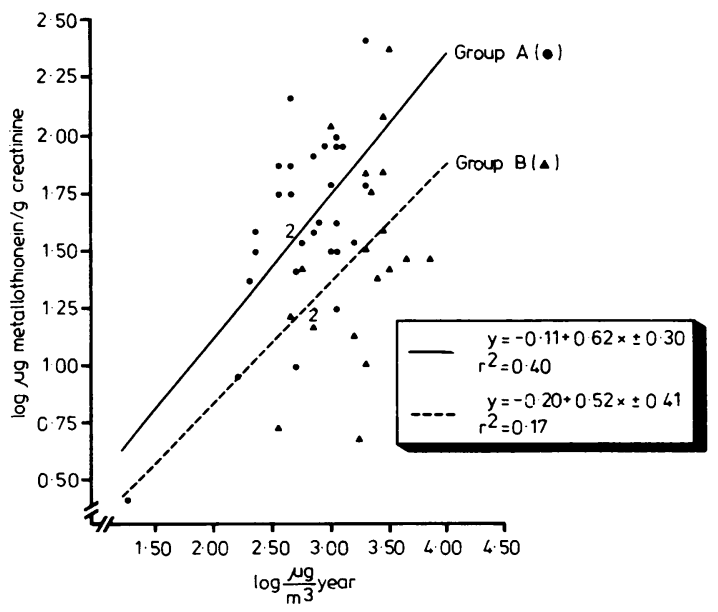

Fig 3 Urinary excretion of metallothionein and cumulative time weighted exposure (ug/ $\mathrm{m}^{3}$ year), cadmium exposed group $A$ and group $B$.

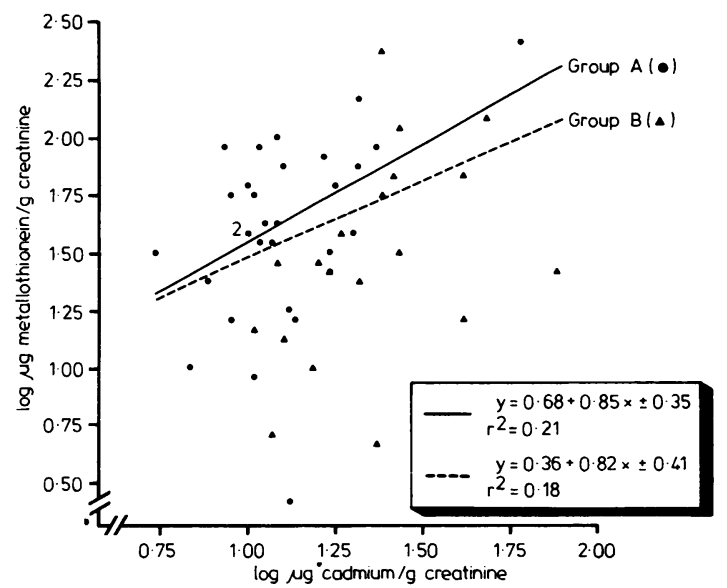

Fig 4 Urinary excretion of metallothionein and cadmium, group $A$ and group $B$.

is no valid reason to remove it, however. These relationships suggest that MT excretion is more highly correlated with cumulative time weighted exposure than $\mathrm{Cd}$ excretion and that MT excretion and $\mathrm{Cd}$ excretion are related.

Serum MT in group $A$ was not significantly related to serum $\beta_{2}-\mathrm{M}\left(\mathrm{r}^{2}=0.01, \mathrm{p}=0.60\right)$, serum creatinine $\left(\mathrm{r}^{2}=0.07, \mathrm{p}=0.15\right)$, or cumulative time weighted exposure $\left(\mathrm{r}^{2}=0.08, \mathrm{p}=0.11\right)$. MT excretion was not significantly linearly related to serum MT $\left(r^{2}=0.07, p=0.13\right)$. Blood Cd concentrations were less than the lower detection limit of $5 \mathrm{ng} / \mathrm{ml}$ for all subjects of group A, thus the relation, if any, between serum MT and blood Cd could not be examined. To determine if MT excretion is a better indicator of exposure than $\beta_{2}-\mathrm{M}$ excretion, in groups $A$ and $B$ partial correlations were computed. ${ }^{16}$ Using this technique the following correlations were found: for MT excretion and cumulative time weighted exposure for groups $\mathrm{A}$ and $\mathrm{B} \mathrm{r}^{2}=0.29$ and 0.19 when $\beta_{2}-\mathrm{M}$ excretion was partialled out, and for $\beta_{2}-M$ excretion and cumulative time weighted exposure for groups $A$ and $B, r^{2}=0.02$ and 0.05 when MT was partialled out. These correlations suggest that MT excretion is a better predictor of cumulative time weighted exposure.

A trend was observed between mean levels of MT excretion and proportion of subjects with an abnormal renal status in groups $A$ and $B$ combined. Logistic regression analysis was done on the proportion of subjects with an abnormal renal status and MT excretion, the level of significance is 0.02 and the $r$ value 0.96 . This finding however, should be interpreted cautiously, since no subjects with abnormal renal function were found in the second stratum when MT excretion in groups A and B were categorised into five strata and the mean MT excretion was used as the independent variable in each strata.

\section{Discussion}

In group A $18 \%$ and in group B $15 \%$ of the subjects were found to have a change in renal function consistent with exposure to $\mathrm{Cd}$. The lower prevalence of renal dysfunction in group $B$ is not compatible with the higher exposures in this group. This could possibly result from the removal of subjects with abnormal renal function, selection bias, or the misclassification of exposure and work histories. Ellis et al studied this entire group and found that the prevalence of renal dysfunction was $23 \%$ among the currently exposed workers $(n=51) .{ }^{17}$

Age, analgesic abuse, and specific medical conditions (see methods) were possible confounding factors in the study, since they can have an effect on renal function. Age, in this study, did not have a significant effect on any of the linear relationships between the variables. Subjects with abnormal renal function and identified (questionnaire) medical conditions that could affect renal function were not used in the statistical analysis of the study data. No cases of analgesic abuse were identified by questionnaire. Smoking habits were also a potential confounding factor, since Cd excretion is significantly higher in smokers. ${ }^{5}$ There was a significant difference in Cd excretion between smokers, non-smokers, and ex-smokers; however, smoking habits had no significant effect on any of the linear relationships regarding $\mathrm{Cd}$ excretion and the other variables.

MT excretion was significantly higher, on the 
average, in subjects with an abnormal versus normal renal status in groups $A$ and $B$ and after pooling groups $A$ and $B$ (table 3 ). Age did not differ significantly in subjects with abnormal versus normal renal function in groups A and B, suggesting that the increased excretion of MT is not an age effect but rather is related, on a group basis, to renal function. MT excretion was also linearly related to protein excretion (fig 1 ) and $\beta_{2}-\mathrm{M}$ excretion (fig 2) in groups $A$ and $B$. This finding seems significant, given that protein excretion and $\beta_{2}-\mathrm{M}$ excretion are indicative of renal function in workers exposed to Cd. ${ }^{18}$ Tohyama et al also found that on a group basis MT excretion was significantly higher in those with renal tubular dysfunction secondary to excessive environmental $\mathrm{Cd}$ exposure. ${ }^{19}$

Serum MT and serum creatinine concentrations were also significantly higher in subjects with abnormal versus normal renal function in group $\mathbf{A}$ (table 3). This relationship suggests that the increased serum MT concentrations are related to a decrease in renal function, since serum creatinine concentration is a reliable predictor of renal function. ${ }^{20}$ These findings also suggest that monitoring MT in the urine or serum may be useful for preventing renal dysfunction resulting from excessive exposure to Cd. The presence of MT in the serum of Cd exposed workers is a significant finding. The serum MT concentration could result from leakage of MT back into the plasma secondary to degeneration or necrosis of renal parenchymal tissue, or both, or MT may be acting as a transport molecule for Cd from the liver to the kidney. If the second hypothesis is true those individuals having increased concentrations of serum MT would accumulate $\mathrm{Cd}$ in the renal cortex more rapidly and, therefore, be at greater risk of developing Cd nephropathy.

The linear relation between MT excretion and cumulative time weighted exposure (group A, $r^{2}=0.40$; group $B, r^{2}=0.17$ ) implies that $M T$ excretion is dose dependent. The variability that exists, especially within group $B$, is to be expected and is the combination of a small sample size, estimation of cumulative time weighted exposure, and interindividual differences in absorption, distribution, metabolism, and excretion. ${ }^{21}$ Group $A$ was found to be more homogeneous than group $B$ when comparing the type of exposure, exposure levels, and characteristics, which also contributed to the differences in variability between the groups and the relationships that were investigated. Cd excretion was not dose dependent (cumulative time weighted exposure) in either group A or group B. This finding is consistent with studies that have reported that urinary $\mathrm{Cd}$ is not related to chronic exposure or body burden, but rather becomes raised when renal dysfunction develops. ${ }^{5} \beta_{2}-M$ excretion was also not significantly correlated, on an individual basis, with cumulative time weighted exposure. Thus on an individual basis the findings in the study suggest that MT is a better indicator of cumulative time weighted exposure than $\mathrm{Cd}$ or $\beta_{2}-\mathrm{M}$ and, therefore, a better predictor of body burden.

The linear relation between MT and Cd excretion agrees with the findings of other investigators, and suggests that MT is concerned in the renal handling of Cd. Chang $e t$ al and Tohyama and Shaikh also found that urinary MT and urinary $\mathrm{Cd}$ in exposed humans were significantly related..$^{22} 23$

Serum MT concentration was not significantly linearly related to cumulative time weighted exposure or MT excretion, which is also in agreement with the findings of Chang et al. ${ }^{22}$ There are several possible explanations for this; the most feasible being that a small molecular weight protein such as MT would be rapidly cleared by the kidney, and only in cases where renal function is impaired would the concentrations be significantly raised.

The findings in this study suggest that MT is related to the nephrotoxicity of Cd. MT was linearly related to protein excretion, $\beta_{2}-\mathbf{M}$ excretion, and cumulative time weighted exposure. The concentrations of MT were also significantly higher in subjects with abnormal renal function, consistent with $\mathrm{Cd}$ exposure. This suggests that MT is a potential biological monitor for $\mathrm{Cd}$ exposure which would be useful for preventing $\mathrm{Cd}$ nephropathy in man. Further studies need to be done to define the kinetics of the renal handling of MT and also to determine if MT is a specific indicator of proximal tubule dynsfunction secondary to Cd exposure. Before MT can be used as a biological monitor for Cd exposure, studies of non-specific nephropathies need to be underaken to validate that MT is not a non-specific indicator of proximal tubule dysfunction such as $\beta_{2}-\mathbf{M}$.

We thank Ms Karen Wilkerson, Ms Barb Brownlee, and Mr John Jarrett for their technical help and Ms Jean Tashian, Ms Pam Chlebek, Ms Doreen McCann, and Mrs Maryann Byrnes for assisting with the preparation of the manuscript. We would also like to thank Dr Arthur Vander for his support of this study.

\section{References}

${ }^{1}$ Kojima Y, Kagi JHR. Metallothionein. Trends In Biochemical Sciences 1978;3:90-2.

${ }^{2}$ Webb M. The chemistry, biochemistry and biology of cadmium. Topics in environmental health. Vol 2. New York: Elsevier/ North-Holland, 1979;205-20. 
${ }^{3}$ Menard MP, McCormick CC, Cousins RJ. Regulation of methallothionein biosynthesis in intestine and liver by dietary zinc. Fed Pro March 1980;39:880.

- Cherian GM, Goyer RA, Richardson-Delaquerriere L. Cadmium-methallothionein induced nephropathy. Toxicol Appl Pharmacol 1976;38:399-408.

${ }^{5}$ Friberg L, Piscator M, Nordberg GF, Kjellstrom T. Cadmium in the environment. 2nd ed. Cleveland: Chemical Rubber Company, 1974:102-5.

- World Health Organisation task group. Health criteria for cadmium. Geneva; WHO 1977. (Summary.)

' Cherian MG, Vostal JJ. On the role of cadmium binding protein in the transport and excretion of cadmium in the rat. Toxicol Appl Pharmacol 1974;29:141.

- Vostal JJ, Cherian MG. Effects of cadmium methalothionein on the renal tubular transport of sodium. Fed Proc March 1974;33:1737.

- Falk FY, Fine LJ, Smith RG, et al. Occupational cadmium exposure and renal status. Am J Ind Med 1983;4:541-9.

${ }^{10}$ Smith TJ, Anderson RJ, Reading JC. Chronic cadmium exposures associated with kidney function effects. Am J Ind Med 1980;1:319-37.

" US Department of Health, Education and Welfare. National Institute for Occupational Safety and Health. NIOSH manual of analytical methods. Washington: DHEW 1974. (HEW publication No (NIOSH) 75-121, 173:1-8.)

12 Bradford MM. A rapid and sensitive method for the quantitation of microgram quantities of protein utilizing the principle of protein-dye binding. Anal Biochem 1976;72:284-54.

${ }^{13}$ Vander Mallie RJ, Garvey JS. Production and study of antibody produced against rat cadmium thionein. Immunochemistry 1978;15:857-68.

14 Vander Mallie RJ, Garvey JS. Radioimmunoassay of metallothioneins. J Biol Chem 1979;254:8416-21.

is Henry JB, ed. In: Todd, Sanford, Davidsohn. Clinical diagnosis and management by laboratory methods. 16th ed. Philadelphia: WB Saunders, 1979: 2094-7.

${ }^{16}$ Neter J, Wasserman W. Applied linear statistical models. Homewood: Irwin, 1974:393-415.

17 Ellis KJ, Morgan WD, Zanzi I, Yasumura S, Vartsky D, Cohn SH. In vivo measurement of critical level of kidney cadmium: dose effect studies in cadmium smelter workers. Am J Ind Med 1980;1:339-48.

12 Kjellstrom T, Evrin P, Rahnster B. Dose-response analysis of cadmium-induced tubular proteinuria. Environ Res 1977;13:303-17.

19 Tohyama C, Shaikh ZA, Nogawa K, Kobayashi E, Honda R. Elevated urinary excretion of metallothionein due to environmental cadmium exposure. In: Toxicology. Vol 20. New York: Elsevier/North Holland, 1981:289-97.

${ }^{20}$ Hook JB. Toxicology of the kidney. Target organ toxicology series. New York: Raven, 1981:1-29.

21 Gompertz D. Assessment of risk by biological monitoring. Br J Ind Med 1981;38:198-201.

${ }^{22}$ Chang CC, Vander Mallie RJ, Garvey JS. A radiommunoassay for human metallothionein. Toxicol Appl Pharmacol 1980;55:94-102.

${ }^{23}$ Tohyama C, Shaikh ZA. Urinary metallothionein as an index of cadmium-induced renal dysfunction in humans. Fed Proc April 1982;41:1226. 